\title{
Changes to the resistome of Pseudomonas aeruginosa clone ST308 associated with corneal infection over time
}

\section{Mahjabeen Khan ${ }^{1}$, Mark D P Willcox ${ }^{1}$, Scott A Rice ${ }^{2}$, Savitri Sharma ${ }^{3}$, Fiona Stapleton ${ }^{1}$}

${ }^{1}$ School of Optometry and Vision Science, UNSW, Sydney, Australia

${ }^{2}$ The Singapore Centre for Environment Life Sciences Engineering (SCELSE) and The School of Biological Sciences, Nanyang Technological University Singapore

${ }^{3}$ LV Prasad Eye Institute Hyderabad, India

9 Corresponding author

20 Email: mahjabeen.khan58@yahoo.com

1 School of Optometry and Vision Science \\ UNSW Sydney Australia.}


- Recent clonal ocular isolates of Pseudomonas aeruginosa from India have acquired a number of resistance genes compared to historical clones

- Consequently, resistance to antibiotics particularly fluoroquinolones in recent clones of $P$. aeruginosa appears to have increased.

- The acquired resistance genes found in the recent $P$. aeruginos $a$ isolates were related to mobile genetic elements.

\section{Abstract}

\section{Objectives}

This study compared the resistomes of isolates of Pseudomonas aeruginosa clone ST308 from 2018 and 1997 from India.

\section{Methods}

41 Two ocular clonal type ST308 isolates of Pseudomonas aeruginosa (198 and 219) isolated in 2018 and five historical isolates $(31,32,33,35$ and 37) isolated in 1997 at the LV Prasad Eye Institute in India were analysed for their susceptibilities to ciprofloxacin, levofloxacin, gentamicin, tobramycin, piperacillin, imipenem, ceftazidime and polymyxin B. DNA was extracted using the DNeasy® Blood and Tissue. Paired-end library was prepared using Nextera XT DNA library preparation kit. Libraries were sequenced on Illumina® MiSeq bench top sequencer generating 300 bp paired-end reads. Spades v3.12.0 was used for assembly, Resfinder v3.1. for acquired resistance genes and Snippy V2 for variants calling. Integron finder v1.5.1 was used to identify the integrons present in the genomes.

\section{Results}


52 The recent isolate 219 was resistant to all tested antibiotics except polymyxin while isolate 198 was resistant to ciprofloxacin, levofloxacin, gentamicin and tobramycin. Among historical isolates five were resistant to gentamicin, tobramycin and ciprofloxacin, four were resistant to levofloxacin while two were resistant to polymyxin. Twenty-four acquired resistance genes were present in the 2018 isolates compared to 11 in the historical isolates.

57 All isolates contained the following genes encoding for aminoglycoside $\operatorname{aph}(6)-I d, \operatorname{aph}\left(3^{\prime}\right)-$ lIb, aph $\left.\left(3^{\prime \prime}\right)-I b\right)$, beta-lactam (blaPAO), tetracycline $(\operatorname{tet}(G)), \quad$ fosfomycin $(f o s A)$, chloramphenicol (catB7), sulphonamide (sul1), quaternary ammonium (qacEdeltal) and fluoroquinolone $(\operatorname{crpP})$ resistance. Isolate 198 possessed aph(3')-VI, rmtD2, qnrVC1, blaOXA-488, blaPME-1, while 219 possessed aadA1, rmtB, aac(6')-Ib-cr, blaTEM-1B, blaVIM-2, $m p h(E), \operatorname{mph}(A), \operatorname{msr}(E)$. In the isolate 219 genes blaTEM-1b, blaVIM-2, sull, qnrvcl, rmtB and aadAl were carried on class 1 integron. While an incomplete class 1 integron was also found in isolate 198 which was located on the genome where gene $r m t B$, blaPME-1, qnrVC1 and sul1 genes were positioned. There were no notable differences in the number of single nucleotide polymorphisms, but recent isolates carried more insertions and deletions in their genes.

P. aeruginosa ocular clonal isolates have changed over time, with strains acquiring genes and having more insertions and deletions in their chromosomal genes that confirm resistance to antibiotics.

DNA extraction, genome sequencing, acquired resistance, single nucleotide polymorphism 


\section{Introduction}

Pseudomonas aeruginosa causes a variety of infections including lung infections in patients with cystic fibrosis, skin infections after burns and corneal infections (microbial keratitis). The increasing prevalence of multidrug resistant (MDR) $P$. aeruginosa reduces the treatment options and complicates management of these infections. Antibiotic resistance occurs mainly due to chromosomal gene mutations and possession of transferrable resistance determinants. [1] MDR isolates can be clonal, particularly those associated with hospital acquired infections. [2]

Clones of $P$. aeruginosa may vary based on the environments [3], and may cause infection outbreaks when these clones enter a new environment. For example, $P$. aeruginosa isolated from water sources can also be isolated from cystic fibrosis patients [4]. Only a few studies have identified clones of ocular isolates of $P$. aeruginosa $[5,6]$. Five multi-drug resistant $P$. aeruginosa isolates from corneal infections have been reported to be clonal and of sequence type 308. [6] The isolates were collected in 1997 from microbial keratitis cases in India. The current study investigated the genomes of more recently collected MDR P. aeruginosa corneal isolates recovered from the same location in India to investigate whether this clonal variant had persisted and whether it had acquired or lost antibiotic resistance genes.

\section{Materials and methods}

\section{$P$. aeruginosa genomic sequencing}

DNA was extracted using DNeasy Blood and Tissue Ki (Qiagen, Hilden Germany) as per the manufacturer's recommendations from two keratitis P. aeruginosa strains 198 and 219 isolated in India in 2018. A paired-end library was prepared using Nextera XT DNA library preparation kit (Illumina, San Diego, CA, USA). All the libraries were multiplexed on one MiSeq run. The raw reads of the sequenced genomes were analysed for their quality using FastQC version 0.117 (https://www.bioinformatics.babraham.ac.uk/projects/fastqc). 
100

101

102

103

104

105

106

107

108

109

110

111

112

113

114

115

116

117

118

Version 0.38 of the Trimmomatic [7] was used for trimming the adapters from the reads following de-novo assembly using Spades v3.13.0 [8]. Genomes were annotated using Prokka v1.12 [9]. Sequence types were investigated using PubMLST https://pubmlst.org/. Resistance genes were identified using online database Resfinder v3.1 (Centre for Genomic Epidemiology, DTU, Denmark) [10]. Mutations in the genes were detected using Snippy V2 [11] using PAO1 as a reference genome. Core genome and pan genomes were analysed using Harvest Suite Parsnp v1.2 and Roary v3.11.2 respectively. Integrons were located using Integron finder v1.5.1. The genes possessed by strains 198 and 219 were then compared to those from other ST308 isolates that had been previously examined [6].

\section{Antibiotic resistance}

Strains 198 and 219 (isolated in 2018) and five strains isolated in 1997 PA31, PA32, PA33, PA35 AND PA37 [6] were screened for resistance to a variety of antibiotics which are commonly used to treat microbial keratitis [12]. The minimum inhibitory concentration (MIC) and minimum bactericidal concentration (MBC) of ciprofloxacin, levofloxacin, gentamicin, ceftazidime (Sigma-Aldrich, St. Louis Missouri, USA), polymyxin B (SigmaAldrich, Vandtårnsvej, Søborg, Denmark) tobramycin, piperacillin (Cayman Chemical Company, Ann Arbor, Michigan, USA) and imipenem (LKT Laboratories Inc, Minnesota, USA) were determined using the broth microdilution method in 96-wells plates following CLSI guidelines. The concentrations of antibiotics tested ranged from $5120 \mu \mathrm{g} / \mathrm{ml}$ to 0.25 $\mu \mathrm{g} / \mathrm{ml}$. The susceptibility results were interpreted using EUCAST v9 [13] and CLSI [14] breakpoints for antibiotics.

\section{Results}

\section{Antibiotic susceptibility and Sequence type analysis}

Isolates 198 and 219 had sequence type 308 indicating that these strains were clonally related to the ST308 strains isolated in 1997 at the same hospital. 
Isolate 219 was resistant to all antibiotics (Table 1 ) other than polymyxin (MIC $=0.5 \mu \mathrm{g} / \mathrm{ml}$,

$\mathrm{MBC}=1 \mu \mathrm{g} / \mathrm{ml})$. Isolate 198 was resistant to ciprofloxacin, levofloxacin, tobramycin and 1997 were all resistant to gentamicin and tobramycin and showed intermediate or definite resistance to imipenem (Table 1). All five isolates from 1997 were resistant or had intermediate resistance to ciprofloxacin and four were resistant to levofloxacin (Table 1). MIC and MBC values to ciprofloxacin and levofloxacin of 198 and 219 were higher than those recorded for the historical isolates (Table 1).

\section{Possession of horizontally-acquired resistance genes}

137 In total 24 acquired resistance genes were present in the ST308 isolates of P. aeruginosa 138 (Table 2). The isolates from 1997 all possessed the same 11 resistance genes. However, the isolates from 2018 had acquired additional resistance genes. Isolate 198 carried 15 and 219 carried 20 resistance genes. Ten resistance genes were common to all seven isolates (Table

2). These ten genes were three aminoglycoside resistance genes ( $a p h(6)-I d, a p h\left(3^{\prime}\right)-l I b$, $\operatorname{aph}\left(3^{\prime \prime}\right)-(b)$, a beta-lactam resistance gene $($ blaPAO), a tetracycline resistance gene $(\operatorname{tet}(G))$, a fosfomycin resistance gene ( fosA), a chloramphenicol resistance gene (catB7) a sulphonamide resistance gene (sul1), and a quaternary ammonium compound resistance gene (qacEdelta1). The recent isolates lacked one beta lactam gene (blaOXA-50) which was present in all the historical isolates.

\section{Aminoglycoside resistance genes}

Strain 198 had acquired a 16S rRNA methylase gene (rmtD2) carried on class 1 integron and three aminoglycoside modifying enzyme genes $a p h(6)-I d$, $a p h\left(3^{\prime}\right)-l I b$, and $\left.a p h\left(3^{\prime \prime}\right)-I b\right)$. Strain 
$(r m t B)$, a streptomycin adenylyltransferase gene (aadA1) carried on class 1 integron and an

aminoglycoside acetyltransferase gene $\left(a a c\left(6^{\prime}\right)-I b-c r\right)$. Strain 219 had also acquired the plasmid related aminoglycoside and fluoroquinolone resistance gene $a a c\left(6^{\prime}\right)-I b-c r$.

\section{Fluoroquinolones resistance genes}

One fluoroquinolone resistance gene, $\operatorname{crp} P$, was present in all isolates from 1997 and 2018. plasmid related aminoglycoside and fluoroquinolone resistance gene $a a c\left(6^{\prime}\right)-I b-c r$ was found in strain 219 and this strain had higher MICs for ciprofloxacin and levofloxacin compared to strain 198 and the 1997 isolates.

\section{Beta-lactam resistance genes}

162 The metallo-beta-lactamase gene class B metallo-b-lactamase blaVIM-2 and a transposon

163 (Tn2) encoded gene blaTEM-1B had been acquired by isolate 219 and were carried on class 1 integron. An extended spectrum plasmid-related class A beta lactamase gene blaPME-1 had been acquired by 198 and were carried on class 1 integron. A class-D beta lactamase gene blaOXA-488 had been acquired by both 198 and 219 .

\section{Non-synonymous mutations in the ST308 resistome}

Table 3 details the non-synonymous mutations leading to changes in the nucleic acid sequence in the resistance genes of these $P$. aeruginosa isolates, including those related to efflux pumps, antibiotic-inactivating enzymes and drug target alterations. These nonsynonymous mutations were made in comparison to the reference genome of strain PAO1. isolates. However, the efflux pump gene $o p m H$ contained 10 SNPs in the isolates from 2018, 
bioRxiv preprint doi: https://doi.org/10.1101/2020.04 10.036673; this version posted April 11, 2020. The copyright holder for this preprint

(which was not certified by peer review) is the author/funder, who has granted bioRxiv a license to display the preprint in perpetuity. It is made available under aCC-BY-ND 4.0 International license.

175 SNPs in the two 2018 isolates. Furthermore, non-synonymous insertions/deletions [15] and

176 frame-shift mutations were found in the two isolates from 2018 (Table 4) whereas the ST308

177 isolates from 1997 had no insertions/deletions or frame-shift mutations [6].

178

179

180

181

182

183

184

185

186

187

188

189

190

191

192

193

194 
196 Table 1. Antibiotic susceptibility of $P$. aeruginosa isolates

\begin{tabular}{|c|c|c|c|c|c|c|c|c|c|c|c|c|c|c|c|c|}
\hline \multirow{2}{*}{$\begin{array}{c}\text { Breakpoints } \\
\qquad P . \\
\text { aeruginosa } \\
\text { Strains of }\end{array}$} & \multicolumn{2}{|c|}{$\begin{array}{l}\text { Ciprofloxacin } \\
\mu \mathrm{g} / \mathrm{ml} \leq 1,2, \geq 4\end{array}$} & \multicolumn{2}{|c|}{$\begin{array}{l}\text { Levofloxacin } \\
\mu \mathrm{g} / \mathrm{ml} \leq 2,4, \\
\geq 8\end{array}$} & \multicolumn{2}{|c|}{$\begin{array}{c}\text { Gentamicin } \mu \mathrm{g} / \mathrm{ml} \\
\leq 4,8, \geq 16\end{array}$} & \multicolumn{2}{|c|}{$\begin{array}{c}\text { Tobramycin } \mu \mathrm{g} / \mathrm{ml} \\
\leq 4,8, \geq 16\end{array}$} & \multicolumn{2}{|c|}{$\begin{array}{l}\text { Piperacillin } \\
\mu \mathrm{g} / \mathrm{ml} \leq 16\end{array}$} & \multicolumn{2}{|c|}{$\begin{array}{c}\text { Imipenem } \\
\mu \mathrm{g} / \mathrm{ml} \leq 2,4, \\
\geq 8\end{array}$} & \multicolumn{2}{|c|}{$\begin{array}{l}\text { Ceftazidime } \\
\mu \mathrm{g} / \mathrm{ml} \leq 8,16, \\
\geq 32\end{array}$} & \multicolumn{2}{|c|}{$\begin{array}{l}\text { Polymyxin } \\
\mu \mathrm{g} / \mathrm{ml} \leq 2 \\
4, \geq 8\end{array}$} \\
\hline & MIC & MBC & MIC & MBC & MIC & MBC & MIC & MBC & MIC & MBC & MIC & MBC & MIC & MBC & MIC & MBC \\
\hline 198 & $1280(\mathrm{R})$ & 2560 & $320(R)$ & 1280 & $2560(R)$ & 5120 & $16(R)$ & 16 & 8 & 8 & 1 & 2 & 8 & 8 & $4(I)$ & 4 \\
\hline 219 & $\geq 5120$ (R) & $\geq 5120$ & $640(R)$ & 1280 & $\geq 5120$ (R) & $\geq 5120$ & 1280 (R) & 2560 & $2560(\mathrm{R})$ & 5120 & $32(R)$ & 64 & $16(I)$ & 32 & 0.25 & 1 \\
\hline 31 & $32(R)$ & 64 & $32(\mathrm{R})$ & 32 & $5120(R)$ & 5120 & $640(R)$ & 1280 & 4 & 8 & $4(I)$ & 16 & $16(I)$ & 32 & $4(I)$ & 4 \\
\hline 32 & $64(R)$ & 128 & $32(R)$ & 32 & $2560(R)$ & 5120 & $640(R)$ & 1280 & 16 & 32 & $4(I)$ & 4 & $16(I)$ & 16 & $4(1)$ & 16 \\
\hline 33 & $128(R)$ & 128 & $32(R)$ & 64 & $2560(R)$ & 5120 & $\geq 5120(R)$ & $\geq 5120$ & $32(R)$ & 64 & $8(\mathrm{R})$ & 16 & $32(R)$ & 64 & 2 & 4 \\
\hline 35 & $2(I)$ & 4 & 2 & 4 & $2560(R)$ & 2560 & $1280(R)$ & 2560 & 8 & 16 & $16(\mathrm{R})$ & 16 & 4 & 8 & 2 & 2 \\
\hline 37 & $64(R)$ & 128 & $32(R)$ & 32 & $2560(R)$ & 2560 & $1280(R)$ & 2560 & 8 & 16 & $8(R)$ & 8 & $16(I)$ & 64 & 2 & 4 \\
\hline
\end{tabular}

$P$. aeruginosa isolates in the light shade are recent and those with dark shading are historical isolates. MIC and MBC values of historical isolates were included from previously published data [6] for all antibiotics except tobramycin and piperacillin. MICs and MBCs of these two antibiotics for the historical isolates and all antibiotics for the recent isolates have been are examined in this study. 
bioRxiv preprint doi: https://doi.org/10.1101/2020.04.10.036673; this version posted April 11, 2020. The copyright holder for this preprint (which was not certified by peer review) is the author/funder, who has granted bioRxiv a license to display the preprint in perpetuity. It is made available under aCC-BY-ND 4.0 International license.

Table 2. Presence of acquired antibiotic resistance genes in $P$. aeruginosa ocular isolates.

\begin{tabular}{|c|c|c|c|c|c|c|c|c|}
\hline $\begin{array}{c}\text { Antibiotic } \\
\text { classes }\end{array}$ & $\begin{array}{c}\text { Resistance } \\
\text { genes }\end{array}$ & 198 & 219 & 31 & 32 & 33 & 35 & 37 \\
\hline \multirow{7}{*}{$\begin{array}{l}\text { Amino- } \\
\text { glycoside }\end{array}$} & $\operatorname{aph}(6)-I d$ & & & & & & & \\
\hline & $\operatorname{aph}\left(3^{\prime}\right)-V I$ & & & & & & & \\
\hline & $a p h\left(3^{\prime}\right)-l I b$ & & & & & & & \\
\hline & $\operatorname{aph}\left(3^{\prime \prime}\right)-I b$ & & & & & & & \\
\hline & aadAl & & & & & & & \\
\hline & $r m t D 2$ & & & & & & & \\
\hline & $r m t B$ & & & & & & & \\
\hline $\begin{array}{c}\text { Fluoroquinolone } \\
+ \\
\text { Aminoglycoside }\end{array}$ & $\begin{array}{l}a a c\left(6^{\prime}\right)-I b- \\
c r\end{array}$ & & & & & & & \\
\hline \multirow{2}{*}{ Fluoroquinolone } & $\operatorname{crpP}$ & & & & & & & \\
\hline & $q n r V C 1$ & & & & & & & \\
\hline \multirow{6}{*}{ Beta lactam } & $\begin{array}{c}\text { blaOXA- } \\
488 \\
\end{array}$ & & & & & & & \\
\hline & blaPAO & & & & & & & \\
\hline & blaOXA-50 & & & & & & & \\
\hline & blaTEM-1B & & & & & & & \\
\hline & blaVIM-2 & & & & & & & \\
\hline & blaPME-1 & & & & & & & \\
\hline $\begin{array}{l}\text { Quaternary } \\
\text { ammonium } \\
\text { compound }\end{array}$ & qacEdeltal & & & & & & & \\
\hline Sulphonamide & sull & & & & & & & \\
\hline Tetracycline & $\operatorname{tet}(G)$ & & & & & & & \\
\hline \multirow{2}{*}{ Macrolide } & $m p h(E)$ & & & & & & & \\
\hline & $m p h(A)$ & & & & & & & \\
\hline $\begin{array}{c}\text { Macrolide, } \\
\text { Lincosamide and } \\
\text { Streptogramin B }\end{array}$ & $m s r(E)$ & & & & & & & \\
\hline Chloramphenicol & catB7 & & & & & & & \\
\hline Fosfomycin & fos $A$ & & & & & & & \\
\hline
\end{tabular}


bioRxiv preprint doi: https://doi.org/10.1101/2020.04.10.036673; this version posted April 11,2020 . The copyright holder for this preprint

(which was not certified by peer review) is the author/funder, who has granted bioRxiv a license to display the preprint in perpetuity. It is made available under aCC-BY-ND 4.0 International license.

Table 3. Single nucleotide polymorphism due to non-synonymous mutations in the genes of

\begin{tabular}{|c|c|c|c|c|c|c|c|c|c|}
\hline \multirow{2}{*}{$\begin{array}{l}\text { Gene } \\
\text { locus }\end{array}$} & \multirow{2}{*}{$\begin{array}{l}\text { Gene } \\
\text { name }\end{array}$} & & \multicolumn{7}{|c|}{ P. aeruginosa/number of SNPs } \\
\hline & & \multirow{35}{*}{$\begin{array}{c}\text { Antibiotic } \\
\text { Efflux }\end{array}$} & 31 & 32 & 33 & 35 & 37 & 198 & 219 \\
\hline PA0156 & triA & & 4 & 5 & 5 & 6 & 5 & $5^{*}$ & $5^{*}$ \\
\hline PA0157 & $\operatorname{triB}$ & & 0 & 0 & 1 & 0 & 0 & 0 & 0 \\
\hline PA0158 & triC & & 2 & 2 & 2 & 2 & 2 & $2^{*}$ & $2^{*}$ \\
\hline PA0424 & $\operatorname{mex} R$ & & 2 & 1 & 1 & 1 & 1 & 1 & 1 \\
\hline PA0426 & $\operatorname{mex} B$ & & 1 & 1 & 2 & 1 & 4 & $2^{*}$ & $2^{*}$ \\
\hline PA1236 & $\operatorname{far} B$ & & 1 & 1 & 1 & 1 & 1 & 1 & 1 \\
\hline PA1282 & $\operatorname{lrfA}$ & & 6 & 6 & 9 & 6 & 8 & $8^{*}$ & $8^{*}$ \\
\hline PA1316 & $\operatorname{lrf} A$ & & 2 & 2 & 2 & 2 & 2 & 2 & 2 \\
\hline PA1435 & mexM & & 4 & 4 & 4 & 4 & 4 & 4 & 4 \\
\hline PA1436 & $m d t C$ & & 2 & 2 & 2 & 2 & 2 & 2 & 2 \\
\hline PA2018 & $\operatorname{mex} Y$ & & 5 & 5 & 5 & 5 & 5 & $5^{*}$ & $5^{*}$ \\
\hline PA2019 & $\operatorname{mex} X$ & & 4 & 4 & 4 & 4 & 4 & 4 & 4 \\
\hline PA2389 & $m a c A$ & & 2 & 1 & 1 & 1 & 1 & 1 & 1 \\
\hline PA2390 & $m a c B$ & & 1 & 1 & 1 & 1 & 1 & 1 & 1 \\
\hline PA2391 & opmQ & & 6 & 5 & 6 & 6 & 6 & $5^{*}$ & $5^{*}$ \\
\hline PA2491 & $\operatorname{mexS}$ & & 2 & 2 & 2 & 2 & 2 & 2 & 2 \\
\hline PA2495 & oprN & & 1 & 1 & 1 & 1 & 1 & 1 & 1 \\
\hline PA2837 & opmA & & 3 & 3 & 3 & 3 & 3 & 3 & 3 \\
\hline PA3019 & taeA & & 1 & 1 & 1 & 1 & 1 & 1 & 1 \\
\hline PA3137 & $\operatorname{far} B$ & & 1 & 1 & 1 & 1 & 1 & 0 & 0 \\
\hline PA3521 & opmE & & 3 & 3 & 3 & 3 & 3 & $3^{*}$ & $3^{*}$ \\
\hline PA3522 & $\operatorname{mex} Q$ & & 4 & 4 & 4 & 4 & 4 & 4 & 4 \\
\hline PA3523 & $\operatorname{mexP}$ & & 2 & 2 & 2 & 2 & 2 & 2 & 2 \\
\hline PA3676 & $\operatorname{mex} K$ & & 1 & 1 & 1 & 1 & 1 & 1 & 1 \\
\hline PA3677 & $\operatorname{mexJ}$ & & 2 & 2 & 2 & 2 & 2 & 2 & 2 \\
\hline PA3678 & $\operatorname{mex} L$ & & 1 & 1 & 1 & 1 & 1 & 1 & 1 \\
\hline PA4205 & $\operatorname{mex} G$ & & 1 & 1 & 1 & 1 & 1 & 1 & 1 \\
\hline PA4206 & $\operatorname{mexH}$ & & 1 & 1 & 1 & 1 & 1 & 1 & 1 \\
\hline PA4207 & mexI & & 1 & 1 & 1 & 1 & 1 & 2 & 1 \\
\hline PA4208 & opmD & & 3 & 3 & 3 & 3 & 3 & $2^{*}$ & $2^{*}$ \\
\hline PA4374 & $\operatorname{mexV}$ & & 2 & 2 & 2 & 2 & 2 & 2 & 2 \\
\hline PA4375 & $\operatorname{mexW}$ & & 2 & 2 & 2 & 2 & 2 & 2 & 2 \\
\hline PA4598 & $\operatorname{mex} D$ & & 2 & 2 & 2 & 2 & 2 & 2 & 2 \\
\hline PA4599 & $\operatorname{mex} C$ & & 7 & 8 & 8 & 8 & 8 & $7^{*}$ & $7^{*}$ \\
\hline
\end{tabular}




\begin{tabular}{|c|c|c|c|c|c|c|c|c|c|}
\hline PA4974 & opmH & & 2 & 1 & 1 & 5 & 5 & $10^{*}$ & $10^{*}$ \\
\hline PA4990 & emrE & & 1 & 1 & 1 & 1 & 2 & 1 & 1 \\
\hline PA4997 & $m s b A$ & & 2 & 3 & 3 & 2 & 3 & $4^{*}$ & $4^{*}$ \\
\hline PA5158 & adeC & & 3 & 3 & 3 & 3 & 3 & $3^{*}$ & $3^{*}$ \\
\hline PA5160 & farB & & 4 & 3 & 3 & 4 & 3 & 3 & 3 \\
\hline PA5518 & $\operatorname{ros} B$ & & 3 & 3 & 3 & 3 & 3 & 2 & 2 \\
\hline PA0706 & catB7 & \multirow{5}{*}{$\begin{array}{l}\text { Antibiotic } \\
\text { inactivation }\end{array}$} & 4 & 4 & 4 & 4 & 4 & 4 & 4 \\
\hline PA4109 & $a m p R$ & & 2 & 2 & 2 & 2 & 2 & $2^{*}$ & $2^{*}$ \\
\hline PA4110 & ampC & & 5 & 5 & 5 & 5 & 5 & 5 & $5 *$ \\
\hline PA4119 & $\begin{array}{c}A p h\left(3^{\prime}\right)- \\
I I b\end{array}$ & & 2 & 2 & 2 & 2 & 2 & 2 & 2 \\
\hline PA5514 & $O X A-50$ & & 1 & 2 & & 3 & 2 & 2 & 2 \\
\hline PA0903 & alaS & \multirow{14}{*}{$\begin{array}{c}\text { Antibiotic } \\
\text { target } \\
\text { alteration }\end{array}$} & 1 & 1 & 1 & 1 & 1 & 1 & 1 \\
\hline PA1972 & $p m r C$ & & 3 & 3 & 3 & 3 & 3 & 3 & 3 \\
\hline PA3002 & $m f d$ & & 1 & 2 & 2 & 2 & 2 & 2 & 2 \\
\hline PA3168 & gyrA & & 1 & 1 & 1 & 1 & 1 & 1 & 1 \\
\hline PA3946 & $\operatorname{ros} C$ & & 6 & 8 & 8 & 7 & 6 & $8^{*}$ & $8^{*}$ \\
\hline PA4265 & tufA & & 1 & 0 & 0 & 0 & 1 & 0 & 0 \\
\hline PA4560 & ileS & & 2 & 2 & 2 & 2 & 2 & 3 & 2 \\
\hline PA4964 & parC & & 2 & 2 & 2 & 2 & 2 & 2 & 2 \\
\hline PA4967 & parE & & 1 & 1 & 1 & 1 & 1 & 1 & 1 \\
\hline PA3554 & $\operatorname{arn} A$ & & 2 & 4 & 4 & 4 & 4 & 3 & $3^{*}$ \\
\hline PA0920 & $m p r F$ & & 6 & 6 & 6 & 6 & 6 & 6 & 6 \\
\hline PA0958 & oprD & & 2 & 1 & 1 & 1 & 4 & $8^{*}$ & $8^{*}$ \\
\hline PA2492 & $\operatorname{mexT}$ & & 3 & 2 & 3 & 5 & 4 & $2^{\dagger}$ & $2^{\dagger}$ \\
\hline PA2020 & mexZ & & 0 & 1 & 1 & 1 & 1 & 1 & 1 \\
\hline
\end{tabular}

$210 \quad(*)$ represents insertions or deletions in the genes, $(\dagger)$ represents frame-shift mutations in the 211 genes

213 Table 4. Insertion/deletion and frame-shift mutation in the resistance genes of the 2018 214 isolates.

\begin{tabular}{|c|c|c|c|}
\hline \multirow{2}{*}{ Gene locus } & \multirow{2}{*}{ Genes } & \multicolumn{2}{|c|}{$\begin{array}{c}\text { Number of deletions and insertions in the } \\
\text { genes }\end{array}$} \\
\cline { 3 - 4 } & & $\mathbf{1 9 8}$ & $\mathbf{2 1 9}$ \\
\hline PA0156 & triA & 2 & 2 \\
\hline PA0158 & triC & 2 & 1 \\
\hline PA0426 & mexB & 1 & 2 \\
\hline PA1282 & lrfA & 2 & 2 \\
\hline
\end{tabular}




\begin{tabular}{|c|c|c|c|}
\hline PA2018 & mexY & 1 & 1 \\
\hline PA2391 & opmQ & 3 & 3 \\
\hline PA3521 & opmE & 1 & 1 \\
\hline PA4208 & opmD & 1 & 1 \\
\hline PA4599 & $m e x C$ & 1 & 8 \\
\hline PA4974 & $o p m H$ & 7 & 2 \\
\hline PA4997 & $m s b A$ & 2 & 1 \\
\hline PA5518 & $a d e C$ & 1 & 1 \\
\hline PA4109 & $a m p R$ & 1 & 2 \\
\hline PA4110 & $a m p C$ & 2 & 2 \\
\hline PA3946 & $\operatorname{rosC}$ & 1 & 6 \\
\hline PA3554 & $a r n A$ & 2 & 6 \\
\hline PA0958 & $o p r D$ & 1Frame-shift deletion & 1Frame-shift deletion \\
\hline PA2492 & $m e x T$ & &
\end{tabular}

\section{Phylogeny of ST308 isolates}

The genomes of these ST308 isolates were aligned using PAO1 as a reference for the core number of core genes to all other isolates (Table 5).

Table 5. Number of genes present in Core and pan genomes of $P$. aeruginosa isolates.

P. aeruginosa isolates

31

32

33

35

37

198

219
Core genes

5445

5447

5440

5442

5450

5454

5451
Total genes

6937

6927

6932

6932

6958

6882

7247 


\section{Discussion}

228

This study examined whether the resistome of the ST308 clone of ocular isolates of $P$. aeruginosa had changed over time. Previously, P. aeruginosa ST308 clones had been reported as multidrug-resistant isolates of nosocomial [16] ocular [6] and canine origin [17]. For the $P$. aeruginosa isolates from three different sources the MIC to imipenem was high which was similar to the finding in the ocular isolates of $P$. aeruginosa in the present study. The ocular isolates of clone ST308 from 2018 had acquired additional resistance genes and had changes in the mutational patterns of the resistance genes compared to ocular isolates from 1997.

Two different variants of $16 \mathrm{~S}$ rRNA methylase, $r m t D 2$ and $r m t B$, related to aminoglycoside resistance were found in the 2018 isolates. These genes have not been reported previously in ST308 but other variants of the same genes have been identified in clones ST316 and ST235 [18] the latter clone being identified as a widespread multi-drug resistance clone. The presence of a larger group of beta lactam resistance genes, specifically those acquired on mobile genetic elements including class A and B metallo-beta lactam genes including blaTEM-1B, blaVIM-2, blaPME-1 carried on integron is a unique finding related to ST308 in the current study. These beta lactam resistance genes have not been reported previously in strains of this clone [6]. However, the possession of sull gene in isolates of present study was similar to the similar ST308 found previously [17]. The possession of blaVIM-2 and blaTEM$1 B$ may have been responsible for the high MIC to piperacillin and imipenem of PA219.

Previously, these genes were associated to increased MIC of imipenem and piperacillin/tazobactam in P. aeruginosa isolates [19].

Metallo-beta lactam genes are usually found on class-1 integrons along with other antibiotic resistance determinants [20] which is similar to the present study but identification of class 1 
integron carrying resistance genes in the ocular $P$. aeruginosa isolates is a novel finding.

These metallo-beta lactam genes are easily transmissible on mobile genetic elements such as transposons, plasmid-integrative conjugative elements and genomic islands. These metallobeta lactam genes (blaTEM-1B, blaVIM-2, blaPME-1) have not been previously reported in ST308 but have been found in ST111 and ST235 [21] [22]. Although different variants of these genes were found in the similar ST308 before [16, 17]. Acquired genes within the mobile genetic elements of ST308 clones were not been identified in an earlier report [6].

Both recent isolates 198 and 219 had acquired genes associated with mobile genetic elements in the current study.

The presence of the plasmid related fluoroquinolone resistance gene qnrVC1 [23] and the recently reported plasmid related gene $\operatorname{crp} P$ [24] are also novel findings in the current study related to clonal ST308 P. aeruginosa isolates. All isolates contained the fluoroquinolone resistance gene $\operatorname{crpP}$, but this had not been identified as a potential plasmid related fluoroquinolone resistance gene prior to the publication of resistance genes of the 1997 isolates [6]. Usually fluoroquinolone resistance is due to mutation in DNA gyrase and topoisomerase IV genes [25]. However, in the 2018 isolates of ST308 very high MICs to ciprofloxacin and levofloxacin might be due to the acquisition of qnrVC1. Strain 219 had also acquired the plasmid related fluoroquinolone resistance gene $a a c\left(6^{\prime}\right)-I b-c r$ [26] which can confer resistance to both fluoroquinolones and aminoglycosides [27]. Previously this gene was found responsible for the 16 to 128 -fold higher MICs for ciprofloxacin in the transconjugants bacteria of family Enterobacteriaceae [28] and MIC of $64 \mu \mathrm{g} / \mathrm{ml}$ of ciprofloxacin to MDR P. aeruginosa isolates [29]. These additional resistance imposing elements to fluoroquinolones suggest that alternative treatments for keratitis other than fluoroquinolone monotherapy should be considered. Acquisition of larger number of aminoglycoside and beta lactam resistance genes is alarming because, where first line therapy 
such as monotherapy with fluoroquinolones fails, fortified antibiotics [30] such as gentamicin plus cephalosporins are often prescribed.

Among all the $P$. aeruginosa isolates, the core genome was composed of almost similar number of genes which was perhaps indicative of the collinear nature of conserved genome of $P$. aeruginosa isolates .[31, 32] However, a larger pan genome of isolate 219 indicates greater genomic diversity due to acquisition of genes from the same or different species or genera. This fact might relate to the larger number of acquired genes in isolate 219 by horizontal gene transfer. [31] Identification of indels (insertion/deletion polymorphisms due to non-synonymous mutations) in the 2018 keratitis isolates of $P$. aeruginosa which were not present in the strains isolated in 1997 [6] as well as the increased presence of certain SNPs suggest that there was an increase in selection pressure in the environment that has selected for these mutations.

Increases in the resistance of keratitis isolates to the fluoroquinolone moxifloxacin have been associated with an increase in average diameter of the infiltrate or scar, a slower time to reepithelialization and decrease in final visual acuity. $[33,34]$ Therefore, the findings from the current study showing that strains of $P$. aeruginosa, at least in this Indian environment, have gained additional resistance genes and higher levels of resistance suggests that treatment of keratitis might be becoming more problematic.

\section{Nucleotide accession}

The nucleotide sequences are available in the GenBank under the Bio project accession number PRJNA590804.

\section{Acknowledgements}

The authors would like to acknowledge the Singapore Centre for Environmental Life Sciences Engineering (SCELSE), whose research is supported by the National Research Foundation Singapore, Ministry of Education, Nanyang Technological University and 
302 National University of Singapore, under its Research Centre of Excellence Programme.

303 Sequencing of DNA was carried out with the help of Stephen Summers using the sequencing

304 facilities at SCELSE. We are also thankful to UNSW high performance computing facility

305 KATANA for providing us cluster time for data analysis.

\section{Conflicts of interest}

307 All the authors declare no conflict of interest.

\section{Authors' contributions}

MW: Conceptualization of the study, manuscript review and editing.

MK: Experimental procedures, genome analysis and writing of the manuscript.

FS: Conceptualization of the study, manuscript review and editing.

SS: Donation of strains and manuscript review.

SR: Genome sequencing facilitation, manuscript review.

All authors have approved the final article

\section{References}

[1] Lister PD, Wolter DJ, Hanson ND. Antibacterial-Resistant Pseudomonas aeruginosa: Clinical Impact and Complex Regulation of Chromosomally Encoded Resistance Mechanisms. Clinical

318 Microbiology Reviews. 2009;22:582-610.

319 [2] Woodford N, Turton JF, Livermore DM. Multiresistant Gram-negative bacteria: the role of highrisk clones in the dissemination of antibiotic resistance. FEMS microbiology reviews. 2011;35:736-55. [3] Romling U, Grothues D, Koopmann U, Jahnke B, Greipel J, Tummler B. Pulsed-field gel electrophoresis analysis of a Pseudomonas aeruginosa pathovar. Electrophoresis. 1992;13:646-8. [4] Römling U, Wingender J, Müller H, Tümmler B. A major Pseudomonas aeruginosa clone common to patients and aquatic habitats. Appl Environ Microbiol. 1994;60:1734-8. evidence for a clone that is pathogenic to the eye and that has a distinct combination of virulence factors. Infection and immunity. 2001;69:6284-95. 
[6] Subedi D, Vijay AK, Kohli GS, Rice SA, Willcox M. Comparative genomics of clinical strains of Pseudomonas aeruginosa strains isolated from different geographic sites. Scientific Reports. 2018;8:15668.

[7] Bolger AM, Lohse M, Usadel B. Trimmomatic: a flexible trimmer for Illumina sequence data. Bioinformatics (Oxford, England). 2014;30:2114-20.

[8] Nurk S, Bankevich A, Antipov D, Gurevich A, Korobeynikov A, Lapidus A, et al. Assembling genomes and mini-metagenomes from highly chimeric reads. In: Deng $M$, Jiang $R$, Sun F, Zhang $X$, editors. Research in Computational Molecular Biology. Berlin, Heidelberg: Springer Berlin Heidelberg; 2013. p. 158-70.

[9] Seemann T. Prokka: rapid prokaryotic genome annotation. Bioinformatics (Oxford, England). 2014;30:2068-9.

[10] Zankari E, Hasman H, Cosentino S, Vestergaard M, Rasmussen S, Lund O, et al. Identification of acquired antimicrobial resistance genes. Journal of Antimicrobial Chemotherapy. 2012;67:2640-4. [11] Seeman T. snippy: fast bacterial variant calling from NGS reads

\section{https://github.com/tseemann/snippy. 2015}

[12] Willcox MDP. Review of resistance of ocular isolates of Pseudomonas aeruginosa and staphylococci from keratitis to ciprofloxacin, gentamicin and cephalosporins. Clinical and Experimental Optometry. 2011;94:161-8.

[13] European Committee on Antimicrobial Susceptibility Testing (EUCAST). Breakpoint tables for interpretation of MICs and zone diameters. Version 6.0: The European Committee on Antimicrobial Susceptibility Testing, 2019.

[14] CLSI. Clinical and Laboratory Standards Institute(CLSI). Performance standards for antimicrobial susceptibility testing; twenty-second information supplement. CLSI document M100-S22 32 (2012). 2012.

[15] Rietveld RP, ter Riet G, Bindels PJ, Sloos JH, van Weert HC. Predicting bacterial cause in infectious conjunctivitis: cohort study on informativeness of combinations of signs and symptoms. Bmj. 2004;329:206-10.

[16] Fournier D, Jeannot K, Robert-Nicoud M, Muller E, Cholley P, van der Mee-Marquet N, et al. Spread of the blalMP-13 gene in French Pseudomonas aeruginosa through sequence types ST621, ST308 and ST111. International Journal of Antimicrobial Agents. 2012;40:571-3.

[17] Wang Y, Wang X, Schwarz S, Zhang R, Lei L, Liu X, et al. IMP-45-producing multidrug-resistant Pseudomonas aeruginosa of canine origin. Journal of Antimicrobial Chemotherapy. 2014;69:257981.

[18] Tada T, Shimada K, Mya S, Zan KN, Kuwahara K, Kirikae T, et al. A New Variant of $16 \mathrm{~S}$ rRNA Methylase, RmtD3, in a Clinical Isolate of <span class="named-content genus-species" id="namedcontent-1">Pseudomonas aeruginosa</span > in Myanmar. Antimicrobial Agents and Chemotherapy. 2018;62:e01806-17.

[19] Quinones-Falconi F, Galicia-Velasco M, Marchiaro P, Mussi MA, Ballerini V, Vila AJ, et al. Emergence of Pseudomonas aeruginosa strains producing metallo- $\beta$-lactamases of the IMP-15 and VIM-2 types in Mexico. Clinical Microbiology and Infection. 2010;16:126-31.

[20] Yu Y-S, Qu T-T, Zhou J-Y, Wang J, Li H-Y, Walsh TR. Integrons containing the VIM-2 metallo- $\beta$ lactamase gene among imipenem-resistant Pseudomonas aeruginosa strains from different Chinese hospitals. Journal of clinical microbiology. 2006;44:4242-5.

[21] Castanheira M, Deshpande LM, Costello A, Davies TA, Jones RN. Epidemiology and carbapenem resistance mechanisms of carbapenem-non-susceptible Pseudomonas aeruginosa collected during 2009-11 in 14 European and Mediterranean countries. Journal of Antimicrobial Chemotherapy. 2014;69:1804-14.

[22] Correa A, Del Campo R, Perenguez M, Blanco VM, Rodríguez-Baños M, Perez F, et al. Dissemination of high-risk clones of extensively drug-resistant Pseudomonas aeruginosa in Colombia. Antimicrobial agents and chemotherapy. 2015;59:2421-5. 
[23] Kocsis B, Toth A, Gulyas D, Ligeti B, Katona K, Rokusz L, et al. Acquired qnrVC1 and blaNDM-1 resistance markers in an international high-risk Pseudomonas aeruginosa ST773 clone. Journal of medical microbiology. 2019;68:336-8.

[24] Chávez-Jacobo VM, Hernández-Ramírez KC, Romo-Rodríguez P, Pérez-Gallardo RV, CamposGarcía J, Gutiérrez-Corona JF, et al. CrpP Is a Novel Ciprofloxacin-Modifying Enzyme Encoded by the Pseudomonas aeruginosa pUM505 Plasmid. Antimicrobial agents and chemotherapy.

2018;62:e02629-17.

[25] Livermore DM. Multiple mechanisms of antimicrobial resistance in Pseudomonas aeruginosa: Our worst nightmare? Clinical Infectious Diseases. 2002;34:634-40.

[26] Ma J, Zeng Z, Chen Z, Xu X, Wang X, Deng Y, et al. High Prevalence of Plasmid-Mediated Quinolone Resistance Determinants $<$ em $>$ qnr $</$ em $>,<$ em $>$ aac $\left(6</\right.$ em $>^{\prime}<$ em $>$ ) $</$ em $>-<$ em $>\mid$ b$\mathrm{cr}</$ em $>$, and $<$ em $>$ qepA $</$ em $>$ among Ceftiofur-Resistant $<$ em $>$ Enterobacteriaceae $</$ em $>$ Isolates from Companion and Food-Producing Animals. Antimicrobial Agents and Chemotherapy. 2009;53:519-24.

[27] Robicsek A, Strahilevitz J, Jacoby GA, Macielag M, Abbanat D, Park CH, et al. Fluoroquinolonemodifying enzyme: a new adaptation of a common aminoglycoside acetyltransferase. Nature medicine. 2006;12:83.

[28] Yang $\mathrm{H}$, Chen $\mathrm{H}$, Yang $\mathrm{Q}$, Chen $\mathrm{M}$, Wang $\mathrm{H}$. High prevalence of plasmid-mediated quinolone resistance genes qnr and aac(6')-lb-cr in clinical isolates of Enterobacteriaceae from nine teaching hospitals in China. Antimicrob Agents Chemother. 2008;52:4268-73.

[29] Araujo BF, Ferreira ML, Campos PA, Royer S, Batistão DW, Dantas RC, et al. Clinical and Molecular Epidemiology of Multidrug-Resistant P. aeruginosa Carrying aac(6')-lb-cr, qnrS1 and blaSPM Genes in Brazil. PloS one. 2016;11:e0155914.

[30] Nixon H. Preparation of fortified antimicrobial eye drops. Kerala Journal of Ophthalmology. 2018;30:152-4.

[31] Klockgether J, Cramer N, Wiehlmann L, Davenport CF, Tümmler BJFim. Pseudomonas aeruginosa genomic structure and diversity. 2011;2:150.

[32] Römling U, Greipel J, Tümmler B. Gradient of genomic diversity in the Pseudomonas aeruginosa chromosome. 1995;17:323-32.

[33] Chen A, Prajna L, Srinivasan M, Mahalakshmi R, Whitcher JP, McLeod S, et al. Does in vitro susceptibility predict clinical outcome in bacterial keratitis? Am J Ophthalmol. 2008;145:409-12. [34] Lalitha P, Srinivasan M, Manikandan P, Bharathi MJ, Rajaraman R, Ravindran M, et al. Relationship of in vitro susceptibility to moxifloxacin and in vivo clinical outcome in bacterial keratitis. Clin Infect Dis. 2012;54:1381-7. 